\title{
Faktor Tampilan dan Penyesuaian Aplikasi pada Kualitas Layanan dalam Menganalisis Loyalitas Pengguna Transportasi Daring
}

\section{Appearance Factors and Application Adjustments to Service Quality in Analyzing Online Transportation User Loyalty}

\author{
Michael Christian ${ }^{{ }^{*}}$ \\ ${ }^{1}$ Program Studi Manajemen, Universitas Bunda Mulia, Jl. Lodan Raya No. 2 Ancol, Jakarta Utara 14430, \\ Indonesia
}

Diterima: 11 Mei, 2020 / Disetujui: 3 Agustus, 2020

\begin{abstract}
The shift in the pattern of using land transportation modes from conventional to online application-based has helped shape the lifestyle pattern of using different land transportation modes for the community. However, the other side of the presence of this application-based online land transportation mode is to maintain customer needs and expectations through aspects of service quality in applications provided by application-based online transportation service providers. It is not an easy thing to do and maintain. Applications should have quality because applications are the main capital in using online transportation modes. In addition, the information listed on the online transportation mode application is an important factor in providing the suitability of the information in the application. This study aims to analyze the effect of application display factors and feature adjustments in the application on user loyalty of application-based online transportation modes. By using SMART PLS 3.0, the results of this study explain that the attitudes of users of application-based online transportation modes are influenced by the application display factors and the adjustment of features in the application. Furthermore, loyalty is influenced by the attitude of users of application-based online transportation modes. Other recent features as part of service quality can be another factor that can be used to analyze user loyalty for applicationbased online transportation modes. This is useful for enriching understanding in determining the loyalty of users of application-based online transportation modes.
\end{abstract}

Keywords: Application display, Adjustment, Attitude, Loyalty

\begin{abstract}
ABSTRAK
Pergeseran pola penggunaan moda transportasi darat dari konvensional menjadi daring berbasis aplikasi turut membentuk pola gaya hidup menggunakan moda transportasi darat yang berbeda bagi masyarakat. Namun demikian, sisi lain dari hadirnya moda transportasi darat daring berbasis aplikasi ini adalah mempertahankan kebutuhan dan ekspektasi pelanggan melalui aspek-aspek kualitas layanan pada aplikasi yang diberikan penyedia jasa moda transportasi daring berbasis aplikasi. Hal ini bukan hal yag mudah untuk dilakukan dan dipertahankan. Aplikasi sebaiknya memiliki kualitas karena aplikasi merupakan modal utama dalam penggunaan moda transportasi daring. Selain itu informasi yang tertera pada aplikasi moda transportasi daring menjadi faktor penting dalam memberikan kesesuaian informasi yang ada di aplikasi. Penelitian ini bertujuan untuk menganalisis pengaruh faktor tampilan aplikasi dan penyesuaian fitur pada aplikasi terhadap loyalitas pengguna moda transportasi daring berbasis aplikasi. Dengan menggunakan SMART PLS 3.0 hasil penelitian ini menjelaskan bahwa sikap pengguna moda transportasi daring berbasis aplikasi dipengaruhi oleh faktor tampilan aplikasi dan penyesuaian fitur yang ada pada aplikasi. Selanjutnya loyalitas dipengaruhi oleh faktor sikap pengguna moda transportasi daring berbasis aplikasi. Fitur-fitur lain terkini sebagai bagian dari kualitas layanan dapat menjadi faktor lain yang dapat digunakan untuk menganalisis loyalitas pengguna moda transportasi daring berbasis aplikasi. Hal ini berguna untuk memperkaya pemahaman dalam menentukan loyalitas pengguna moda transportasi daring berbasis aplikasi.
\end{abstract}

Kata kunci: Tampilan aplikasi, Penyesuaian, Sikap, Loyalitas

*email: michaelchristianid@gmail.com 


\section{PENDAHULUAN}

Perkembangan teknologi telah menggeser pola konsumsi masyarakat di Indonesia termasuk mengenai penggunaan transportasi darat. Transportasi darat telah menghadirkan transportasi daring berbasis daring yang telah menjadi salah satu pilihan moda transportasi darat. Namun demikian moda transportasi daring berbasis aplikasi pada prosesnya memiliki kelemhan yaitu masih terjadinya perselihan antara mitra moda transportasi daring berbasis aplikasi dengan mitra ojek konvensional, membentuk rasa malas bagi masyarakat untuk membeli makanan, dan menyebabkan keinginan para pekerja untuk keluar dari perusahaan untuk bergabung menjadi mitra (Nandi, 2019). Menurut riset yang dilakukan oleh Google, Temasek dan Bain \& Company menjelaskan bahwa pangsa pasar layanan transportasi daring berbasis aplikasi khususnya di Indonesia menunjukkan angka tertinggi di antara negara-negara di ASEAN yaitu sebesar US\$ 5,7 miliar. Selanjutnya penelitian tersebut melakukan prediksi pangsa pasar di tahun 2025 dimana dijelaskan juga Indonesia merupakan negara dengan pangsa pasar tertinggi mengungguli jauh negara-negara di Asia Tenggara dengan angka mencapai US\$ 18 miliar. Hal ini menjelaskan bahwa moda transportasi daring berbasis aplikasi daring di Indonesia telah berhasil menjadi pilihan yang cukup dipertimbangkan bagi masyarakat sebagai pilihan moda transportasi darat. Hal ini semakin didukung dengan populasi penduduk di Indonesia.

Selain faktor jumlah penduduk, nyatanya perkembangan transportasi daring berbasis aplikasi di Indonesia juga disokong oleh faktor investasi dari berbagai pihak. Investor-investor yang menyokong dana besar bagi Gojek seperti Google, Temasek, Warburg Pincus dan Tencent. Sementara itu Grab tidak ketinggalan dengan investor besar di belakang layar seperti SoftBank, Microsoft, dan Didi Chuxing (The
Financial Times, 2019). Kedua layanan moda transportasi daring berbasis aplikasi ini merupakan pemain besar dan utama di Indonesia walaupun di masa pandemi ini, kedua penyedia jasa moda transportasi daring berbasis aplikasi ini mengalami penurunan pengguna. Berdasarkan data Statqo (Lokadata, 2020), pada tanggal 13 Maret 2020 jumlah pengguna moda transportasi daring berbasis aplikasi sebesar 3,15 juta (Gojek) dan 2,51 juta (Grab) yang kemudian pada tanggal 26 Maret 2020 mengalami penurunan pengguna menjadi 2,57 juta (Gojek) dan 2,01 juta pengguna (Grab).

Penelitian di beberapa wilayah di Indonesia mengenai keputusan pengguna memilih moda transportasi daring berbasis aplikasi dipengaruhi oleh ragam faktor. Keputusan pengguna di Bandung memilih moda transportasi daring berbasis aplikasi dilatarbelakangi oleh beberapa faktor seperti mendukung mobilitas pengguna, memungkinkan jangkauan yang luas untuk tempat tujuan, menjadikan layanan ojek lebih terkoordinasi, dan membentuk transparansi biaya antar (Nandi, 2019). Fariza Dewi \& Mahfudz (2018) menjelaskan bahwa preferensi pengguna di Semarang ditentukan dari kesesuaian ekspektasi dan pola gaya hidup menjadikan moda transportasi daring berbasis aplikasi menjadi pilihan. Secara spesifik Novia \& Andarini (2019) menjelaskan bahwa faktor risiko dan personality mitra yang mencerminkan kualitas layanan menjadi pembentuk persepsi yang menentukan pilihan penggunaan moda transportasi daring berbasis aplikasi di Jawa Timur. Dari aspek kualitas layanan, Muis, Fathoni, \& Minarsih (2018) menjelaskan beberapa faktor seperti kesopanan, keramahtamahan, pelayanan yang baik, kecepatan dan ketepatan waktu menjadi penentu kepuasan penggunaan moda transportasi daring berbasis aplikasi. Kinerja bisnis dipengaruhi oleh penggunaan teknologi yang digunakan (Christian, 2019a).

Tabel 1. Pangsa Pasar Transportasi Daring di Asia Tenggara

\begin{tabular}{|c|c|c|c|}
\hline Negara & 2015 (US\$) & 2019 (US\$) & 2025 (US\$) \\
\hline Indonesia & 1 miliar & 5,7 miliar & 18 miliar \\
\hline Singapura & 0,8 miliar & 2,9 miliar & 7 miliar \\
\hline Thailand & 0,4 miliar & 1,3 miliar & 5 miliar \\
\hline Filipina & 0,3 miliar & 0,8 miliar & 4 miliar \\
\hline Vietnam & 0,2 miliar & 1,1 miliar & 4 miliar \\
\hline Malaysia & 0,3 miliar & 0,9 miliar & 3 miliar \\
\hline
\end{tabular}

Sumber: Katadata (2019) 


\subsection{Tampilan}

Aplikasi merupakan modal utama dalam penggunaan moda transportasi daring berbasis aplikasi. Terdapat beberapa pendapat yang menjelaskan mengenai faktor-faktor yang mencakup tampilan aplikasi moda transportasi daring. Artikel ini menjelaskan aplikasi yang digunakan pada moda transportasi daring sebaiknya memiliki kualitas. Hal ini menjadikan faktor tampilan fisik memiliki tingkat kepuasan dan kepentingan yang tinggi (Mayanda, Wijayanto dan Muflikhati, 2018). Kualitas layanan dalam bidang transportasi daring berbasis aplikasi dibentuk oleh beberapa faktor seperti efisiensi (menghemat energi dalam penggunaan) dan kualitas dari informasi yang diberikan (Hendrayati, Askolani, Achyarsyah, Sudrajat, \& Syahidah, 2020; Chang, Lee, \& Lai, 2012). Dalam kaitannya dengan tampilan aplikasi transportasi daring, kemudahan dalam fitur yang digunakan menjadi faktor penting dalam membentuk keputusan penggunaan moda transportasi berbasis daring. Selain itu informasi yang tertera pada aplikasi moda transportasi daring menjadi faktor penting dalam memberikan kesesuaian informasi yang ada di aplikasi. Kualitas informasi yang tersedia di aplikasi sebaiknya tetap harus didukung oleh kinerja mitra dan kondisi kendaraan yang digunakan (Heidari, Mousakhani dan Rashidi, 2014). Hal yang harus dihindari adalah membuat tampilan yang membingungkan dan menyulitkan penggunaan yang dapat membuat stress penggunaan teknlogi (Christian, Purwanto dan Wibowo, 2020). Tampilan iklan yang terlalu banyak dan mengganu dapat memunculkan sikap skeptis dan Tindakan menghindari (Christian, 2019b). Berdasarkan penjelasan yang telah dipaparkan, maka hipotesis ayang dibetuk dalam penelitian ini yaitu:

\section{H1: Tampilan aplikasi memberikan pengaruh signifikan terhadap sikap pengguna}

\subsection{Penyesuaian}

Loyalitas pada loyalitas dalam konteks konvensional (luring) dengan daring memiliki perbedaan, khususnya pada sifat layanan dan fitur (Díez, Coronado dan Rodrigues, 2012) yang diberikan kepada pelanggan. Hal yang menjadi tantangan dalam mengelola kualitas layanan berbasis daring yaitu kemampuan memahami kebutuhan pelanggan dan pengembangan tampilan yang sudah ada (Barnes dan Vidgen, 2002). Kualitas layanan yang ditampilan pada website yang dikelola secara berkesinambungan dapat membentuk keberhasilan tujuan yang ingin dicapai (Zeithaml, Parasurarnan dan Malhotra, 2002), salah satu diantaranya yaitu terbentuknya loyalitas pelanggan. Lin \& Hsieh (2011) menjelaskan bahwa salah satu aspek yang dapat membentuk ekspektasi pelanggan pada layanan teknologi self-service adalah adanya penyesuaian pada preferensi pengguna. Dengan demikian, berdasarkan penjelasan di atas, maka hipotesis berikutnya dalam penelitian ini yaitu:

H2: Penyesuaian fitur dan informasi pada aplikasi memberikan pegaruh terhadpa sikap pengguna

Tabel 2. Pengembangan Indikator

\begin{tabular}{llll}
\hline Dimensi & \multicolumn{1}{c}{ Definisi } & \multicolumn{1}{c}{ Item } & TamAp1 \\
\hline Tampilan & Tampilan sebuah situs mulai dari & Informasi-informasi di luar fitur (misal: & \\
Aplikasi & susunan fitur, warna, informasi, & promo, diskon) yang ada pada aplikasi ini & \\
& dan estetika tampilan & ditampilkan dengan menarik & TamAp2 \\
& & Tata letak yang ada di aplikasi jasa moda & \\
& & transportasi berbasis daring (online) disusun & \\
& menarik & Warna yang digunakan di aplikasi jasa moda & TamAp3 \\
& transportasi berbasis daring (online) ini & TamAp4 \\
& menarik & & \\
& & Perasaan puas dengan desain yang ada di & \\
& aplikasi jasa moda transportasi berbasis & & \\
& daring (online $)$ &
\end{tabular}




\begin{tabular}{|c|c|c|c|}
\hline Dimensi & Definisi & Item & \\
\hline \multirow[t]{3}{*}{ Penyesuaian } & $\begin{array}{l}\text { Penyesuaian tingkat service yang } \\
\text { diberikan oleh sebuah aplikasi } \\
\text { terhadap keinginan dan }\end{array}$ & $\begin{array}{l}\text { Jasa moda transportasi berbasis daring } \\
\text { (online) telah memenuhi kebutuhan saya } \\
\text { akan moda transportasi dara }\end{array}$ & Pny1 \\
\hline & kebutuhan pengguna & $\begin{array}{l}\text { Aplikasi jasa moda transportasi berbasis } \\
\text { daring (online) menyediakan pilihan fitur } \\
\text { moda transportasi yang diperlukan (misal: } \\
\text { roda } 2 \text {, roda } 4 \text { ) }\end{array}$ & Pny2 \\
\hline & & $\begin{array}{l}\text { Aplikasi jasa moda transportasi berbasis } \\
\text { daring (online) memberikan nilai manfaat }\end{array}$ & Pny3 \\
\hline \multirow[t]{2}{*}{ Sikap } & $\begin{array}{l}\text { Hasil yang menguntungkan atau } \\
\text { tidak menguntungkan terhadap } \\
\text { layanan aplikasi }\end{array}$ & $\begin{array}{l}\text { Aplikasi jasa moda transportasi berbasis } \\
\text { daring (online) merupakan aplikasi yang } \\
\text { berharga dalam penyediaan jasa transportasi } \\
\text { berbasis daring di DKI Jakarta }\end{array}$ & Skp1 \\
\hline & & $\begin{array}{l}\text { Secara keseluruhan, aplikasi jasa moda } \\
\text { transportasi berbasis daring (online) } \\
\text { membantu }\end{array}$ & Skp3 \\
\hline Loyalitas & $\begin{array}{l}\text { Pembelian atau penggunaan } \\
\text { berulang }\end{array}$ & $\begin{array}{l}\text { Menyadari secara spontan saya akan } \\
\text { memutuskan untuk lebih menggunakan moda } \\
\text { transportasi berbasis daring (online) } \\
\text { dibandingkan dengan moda transportasi } \\
\text { konvensional (koginitif) }\end{array}$ & Lyt1 \\
\hline
\end{tabular}

Sumber: diolah peneliti

\subsection{Sikap}

Mengelola pelanggan merupakan upaya untuk mempertahankan hubungan dengan pelanggan. Dalam konteks pemasaran, hal ini dikenal dengan konsep Customer Relattionship Management (CRM). Tujuan akhir dari CRM adalah tetap meningkatkan tingkat kepuasan pelanggan sekaligus loyalitas pelanggan. Hal ini dapat dibentuk dengan melakukan integrasi optimal dari aspek teknologi, sumber daya manusia yang terlibat, dan proses bisnis (Shukla \& Pattnaik, 2019; H Hendrayati \& Syahidah, 2018). Loyalitas merupakan refleksi dari perilaku individu untuk melakukan pembelian ulang produk (Hendrayati et al., 2020). Keinginan untuk pembelian ulang dapat didefinisikan sebagai pembelian produk untuk yang kedua kali dan seterusnya baik untuk produk yang sama maupun variasi/berbeda (Zeng et al., 2009). Loyalitas juga ditentukan oleh nilai dan kepercayaan yang dirasakan pelanggan (Zehir dan Narcıkara, 2016). Hal ini semakin menjelaskan bahwa loyalitas penggunaan dipengaruhi oleh sikap yang terbentuk di masing-masing individu sebagai pengguna. Berdasarkan penjelasan-penjelasan yang ada, maka hipotesis terakhir dalam penelitian ini yaitu:

\section{H3: Sikap individu memberikan pengaruh terhadap loyalitas pengguna}

\section{METODOLOGI}

Penelitian ini merupakan penelitian kuantitatif dengan menggunakan survey. Kuesioner digunakan sebagai instrument penelitian. Analisis penelitian menggunakan model struktural dengan SMART PLS 3.0. Sampel penelitian merupakan pengguna moda transportasi daring berbasis aplikasi di Jakarta. Jumlah sampel dalam penelitian ini sebesar 140 yang diperoleh dari perkalian jumlah indikator 
dengan 5 sampai dengan 10 (Hair et al., 2014). Uji yang digunakan dalam penelitian ini yaitu uji validitas, reliabilitas, kesesuaian model konstruk dan uji hipotesis.

\section{HASIL DAN PEMBAHASAN}

Sampel penelitian ini terdiri dari pengguna perempuan sebanyak 73 orang $(52,14 \%)$ dan laki-laki sebanyak 67 orang $(47,86 \%)$. Berdasarkan hasil ini, responden penelitian yang paling dominan yaitu responden perempuan dibandingkan laki-laki. Tingkat keseringan dalam penggunaan moda transportasi daring berbasis daring yang lebih banyak digunakan yaitu Gojek sebanyak 81 orang $(57,86 \%)$ dan Grab sebanyak 59 orang $(42,14 \%)$. Hasil ini menjelaskan bahwa Gojek masih memiliki awareness khusus yang lebih tinggi bagi pengguna moda transportasi daring berbasis aplikasi dibandingkan Grab.

\subsection{Validitas dan Reliabilitas}

Gambar 1 menujukkan hasil outer loadings dimana seluruh angkanya berada di atas angka 0,7. Hasil ini menjelaskan bahwa seluruh item pada penelitian ini dikatakan valid.

Average Variance Extracted (AVE) pada Tabel 3 menunjukkan angka variabel yaitu Tampilan Aplikasi, Penyesuaian, Sikap dan Loyalitas dimana semuanya berada di atas 0,5 . Hasil ini menjelaskan bahwa variabel-variabel yang ada bersifat valid. Kolom Cronbach's Alpha yang menunjukkan angka di atas 0,7 dapat menjelaskan konstruk yang ada bersifat reliabel. Begitu juga dengan kolom Composite Reliability yang menunjukkan angka pada semua variabel yang berada di atas angka 0,7. Hasil ini menjelaskan keandalan pada semua variabel yang ada. Dari hasil ini maka dapat dikatakan konstruk yang ada dalam penelitian ini bersifat sahih dan andal.

\subsection{Uji Hipotesis}

Uji hipotesis dapat dijelaskan berdasarkan hasil pada tabel 4. Pada koefisien parameter Tampilan Aplikasi $\rightarrow$ Sikap, menunjukkan angka pada T-statistics sebesar 4,844 $(>1,96)$ yang menjelaskan sikap pengguna moda transportasi daring berbasis aplikasi dipengaruhi oleh faktor Tampilan Aplikasi moda transportasi daring itu sendiri. Angka pada $p$-values $(0,000)$ menjelaskan bahwa pengaruh Tampilan Aplikasi $\rightarrow$ Sikap bersifat signifikan. Berdasarkan hasil inimaka dapat dijelaskan bahwa bahwa Hipotesis 1 diterima. Dalam kaitannya dengan kualitas layanan dimana tampilan aplikasi tercakupnya di dalamnya, hasil ini sejalan dengan penelitian yang dilakukan Hendrayati, Askolani, Achyarsyah, Sudrajat, \& Syahidah (2020) dan Chang, Lee, \& Lai (2012).

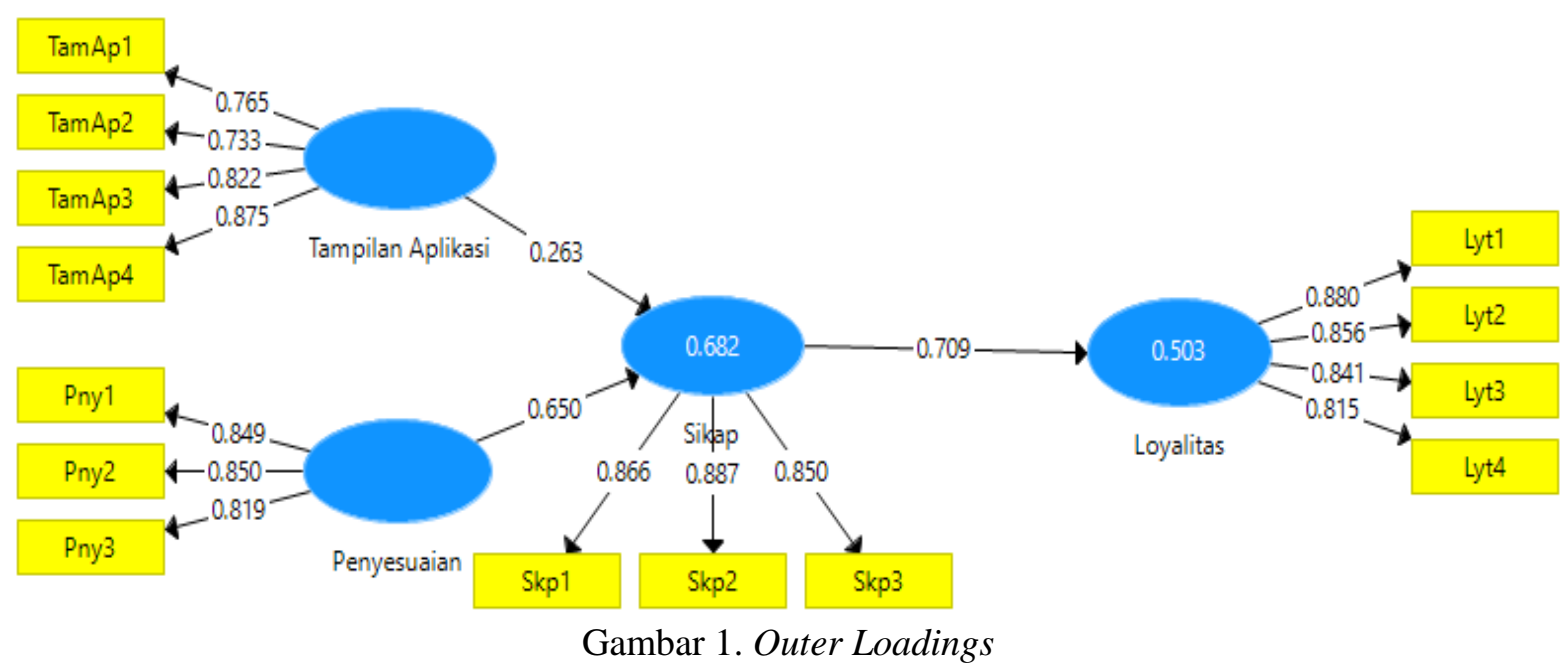

Sumber: SMART PLS 3.0; $n=-140$ 
Tabel 3. Uji Validitas dan Reliabilitas

\begin{tabular}{lcccc}
\hline & Cronbach's Alpha & Composite Reliability & AVE & Keterangan \\
\hline Tampilan Aplikasi & 0,813 & 0,877 & 0,641 & Valid \& reliabel \\
Penyesuaian & 0,791 & 0,877 & 0,704 & Valid \& reliabel \\
Sikap & 0,836 & 0,901 & 0,753 & Valid \& reliabel \\
Loyalitas & 0,872 & 0,911 & 0,720 & Valid \& reliabel \\
\hline
\end{tabular}

Sumber: SMART PLS 3.0; $n=-140$

Tabel 4. Uji Hipotesis

\begin{tabular}{lccc}
\multicolumn{1}{c}{ Path } & T-Statistics $(\mid$ O/STDEV $\mid)$ & P Values & Hasil \\
\hline Tampilan Aplikasi $\rightarrow$ Sikap & 4,844 & 0,000 & H1 diterima \\
Penyesuaian $\rightarrow$ Sikap & 12,678 & 0,000 & H2 diterima \\
Sikap $\rightarrow$ Loyalitas & 17,744 & 0,000 & H3 diterima \\
\hline
\end{tabular}

Sumber: SMART PLS $3.0 ; n=-140$

Selanjutnya koefisien parameter Penyesuaian $\rightarrow$ Sikap, $T$-statistics menunjukkan angka sebesar 12,678 $(>1,96)$ yang menjelaskan sikap pengguna moda transportasi daring berbasis aplikasi dipengaruhi oleh faktor Penyesuaian pada aplikasi moda transportasi daring yang ada. Angka pada $p$-values $(0,000)$ menjelaskan bahwa pengaruh Penyesuaian $\rightarrow$ Sikap bersifat signifikan. Berdasarkan hasil inimaka dapat dijelaskan bahwa bahwa Hipotesis 2 diterima. Seperti yang telah dijelaskan di atas bahwa penyesuaian merupakan bagian dari kualitas layanan moda transportasi daring berbasis aplikasi. Dengan demikian dapat dijelaskan bahwa hasil penelitian ini sejalan dengan dengan Lin \& Hsieh (2011), Barnes \& Vidgen (2002) dan Zeithaml, Parasurarnan, \& Malhotra, (2002). Koefisien parameter Sikap $\rightarrow$ Loyalitas menunjukkan angka sebesar 17,744 (>1,96) yang menjelaskan bahwa Loyalitas pengguna dipengaruhi oleh Sikap pengguna moda transportasi daring berbasis aplikasi. Angka pada $p$-values $(0,000)$ menjelaskan bahwa pengaruh Sikap $\rightarrow$ Loyalitas bersifat signifikan. Berdasarkan hasil inimaka dapat dijelaskan bahwa bahwa Hipotesis 3 diterima. Hasil ini mendukung penelitian yang dilakukan oleh Heny Hendrayati et al., (2020), Shukla \& Pattnaik (2019), dan Zehir \& Narcıkara, (2016).

\section{SIMPULAN}

Berdasarkan hasil dan pembahasan di atas, simpulan penelitian ini dapat dijelaskan bahwa sikap pengguna moda transportasi daring berbasis aplikasi dipengaruhi oleh faktor tampilan aplikasi moda transportasi daring. Selanjutnya penelitian ini juga menjelaskan bahwa sikap pengguna moda transportasi daring berbasis aplikasi juga dipengaruhi oleh faktor penyesuaian pada aplikasi moda transportasi daring yang ada. Pada bagian akhir simpulan dapat dijelaskan bahwa loyalitas pengguna dipengaruhi oleh sikap pengguna moda transportasi daring berbasis aplikasi. Ragam fitur yang telah disesuaikan sebagai bagian dari kualitas layanan dapat menjadi faktor tambahan yang penting dalam mengukur loyalitas pengguna moda transportasi daring berbasis aplikasi.

\section{DAFTAR PUSTAKA}

Barnes, S. J. dan Vidgen, R. T. (2002) "An Integrative Approach to the Assessment of E-commerce Quality," Journal of Electronic Commerce Research, 3, hal. 114-127.

Chang, H. ., Lee, C. . dan Lai, C. . (2012) "EService Quality and Relationship Quality on Dealer Satisfaction: Channel Power as a Moderator," Total Quality Management \& Business Excellence, 23(7-8), hal. 855-873.

Christian, M. (2019a) "Dampak Penggunaan Teknologi Berbasis Aplikasi pada Usaha Restoran Berskala Mikro \& Kecil," Journal of Business and Applied Management, 12(2), hal. 132-198. doi: 10.30813/jbam.v12i2.1822.

Christian, M. (2019b) "Telaah Keniscayaan Iklan di Kanal Youtube sebagai Perilaku Khalayak di Kalangan Milenial," Bricolage: Jurnal Magister Ilmu Komunikasi, 5(2), hal. 141-158. doi: 10.30813/bricolage.v5i02.1890.

Christian, M., Purwanto, E. dan Wibowo, S. (2020) "Technostress Creators on Teaching Performance of Private 
Universities in Jakarta During Covid-19 Pandemic," Technology Reports of Kansai University, 62(6).

Díez, I. T., Coronado, L. L. dan Rodrigues, J. J. P. (2012) "Howtomeasure the QoS of a Web-based EHRs System: Development of an Instrument," Journal of Medical Systems, 36, hal. 3725-3731.

Fariza Dewi, F. dan Mahfudz (2018) "Pengaruh Citra Merek, Preferensi Konsumen, Word of Mouth, Kepercayaan, dan Persepsi Harga terhadap Keputusan Pembelian Jasa Go-Ride (Studi pada Mahasiswa Universitas Diponegoro)," Diponegoro Journal of Management, 7(2), hal. 1-13.

Hair, J. F. et al. (2014) Multivariate Data Analysis. 7 ed. London: Pearson Education Limited.

Heidari, H., Mousakhani, M. dan Rashidi, H. (2014) "The Impact of Traditional and Electronic Service Quality on Customer Satisfaction, Trust and Loyalty in Banking Industry," International Journal of Scientific Management and Development, 2, hal. 614-620.

Hendrayati, H. et al. (2020) "E-Service Quality and Price to Build Online Transportation Loyalty in Indonesia," Journal of Management and Marketing Review, 5(1), hal. $16-30$.

Hendrayati, H. dan Syahidah, R. K. (2018) "Barriers and Possibilities of Implementation of Customer Relationship Management on Small and Medium Enterprises by Womenpreneurs," Jurnal Bisnis dan Manajemen, 19(2), hal. 72-87.

Katadata (2019) Berapa Pangsa Pasar Jasa Layanan Transportasi Online Indonesia?, katadata.co.id. Tersedia pada:

https://databoks.katadata.co.id/datapublis h/2019/10/05/berapa-pangsa-pasar-jasalayanan-transportasi-online-indonesia (Diakses: 27 Juli 2020).

Lin, J. S. . dan Hsieh, P. . (2011) "Assesing the Self-Service Technology Ecounters: Development and Validation of SSTQUAL Scale," Journal of Retailing, 87, hal. 194-206.

Lokadata (2020) Penumpang Angkutan Daring Turun, Tapi Terbuka Peluang Lain, lokadata.id. Tersedia pada: https://lokadata.id/artikel/penumpang- angkutan-daring-turun-tapi-terbukapeluang-lain (Diakses: 27 Juli 2020).

Mayanda, L., Wijayanto, H. dan Muflikhati, I. (2018) "Factors Affecting Satisfaction and Loyalty of Online Taxi-Motor Partners," Indonesian Journal of Business and Entrepreneurship, 4(2), hal. 207216.

Muis, A., Fathoni, A. dan Minarsih, M. M. (2018) "Analisis Faktor-faktor yang Mempengaruhi Kepuasan Konsumen terhadap Pengguna Transportasi Go-Jek di Semarang," Journal of Management, 4(4).

Nandi (2019) "The Influence of Online Transportation Application to the Mobility and Economic of the Society (Case Study on Using Grab and Go-Jek in Bandung, Indonesia)," in IOP Conference Series: Earth and Environmental Science. Tanjung Malim: IOP Science, hal. 1-6.

Novia, C. dan Andarini, S. (2019) "Analisis Komparasi Persepsi Konsumen Pengguna Ojek Online Go-Ride dan Grab Bike (Studi Kasus pada Mahasiswa Pengguna Ojek Online Go-Ride dan Grab-Bike di UPN Veteran Jawa timur)," Jurnal Bisnis Indonesia, 10(2), hal. 224-237.

Shukla, M. K. dan Pattnaik, P. N. (2019) "Managing Customer Relations in A Modern Business Environment: Towards an Ecosystem-based Sustainable CRM Model," Journal of Relationship Marketing, 18(1), hal. 17-33.

The Financial Times (2019) Grab v Gojek: Inside the Tech Battle for South-east Asia. Tersedia pada: https://www.ft.com/content/04e0523c2256-11ea-b8a1-584213ee7b2b (Diakses: 27 Juli 2020).

Zehir, C. dan Narcikara, E. (2016) "E-Service Quality and E-Recovery Service Quality: Effects on Value Perceptions and Loyalty Intentions," Procedia - Social and Behavioral Sciences, 229, hal. 427 - 443.

Zeithaml, V. A., Parasurarnan, A. dan Malhotra, A. (2002) "Service Quality Delivery Through Web Sites: A Critical Review of Extant Knowledge," Journal of the Academy ofMarketing Science, 30, hal. 362-375.

Zeng, F. et al. (2009) "Determinants of Online Service Satisfaction and Their Impacts on Behavioural Intentions," Total Quality 
Management \& Business Excellence, 20(9), hal. 953-969. 